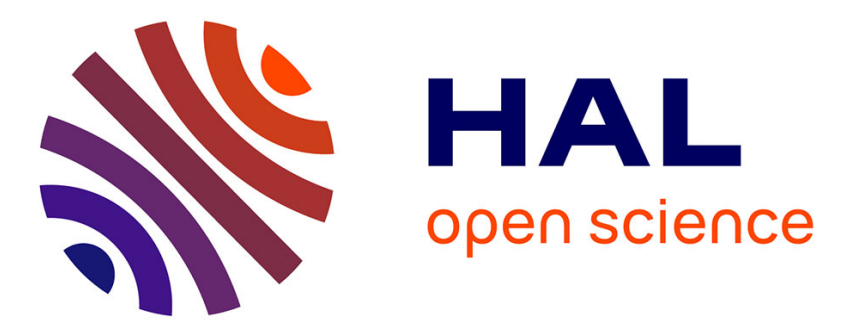

\title{
Pharmacological insight into the activation of the human Neuropeptide FF2 receptor
}

Franck Talmont, Remi Veneziano, Gilles Dietrich, Lionel Moulédous, Catherine Mollereau, Jean-Marie Zajac

\section{- To cite this version:}

Franck Talmont, Remi Veneziano, Gilles Dietrich, Lionel Moulédous, Catherine Mollereau, et al.. Pharmacological insight into the activation of the human Neuropeptide FF2 receptor. Peptides, In press, 134, pp.170406. 10.1016/j.peptides.2020.170406 . hal-02939290

\section{HAL Id: hal-02939290 \\ https://hal.science/hal-02939290}

Submitted on 18 Nov 2020

HAL is a multi-disciplinary open access archive for the deposit and dissemination of scientific research documents, whether they are published or not. The documents may come from teaching and research institutions in France or abroad, or from public or private research centers.
L'archive ouverte pluridisciplinaire HAL, est destinée au dépôt et à la diffusion de documents scientifiques de niveau recherche, publiés ou non, émanant des établissements d'enseignement et de recherche français ou étrangers, des laboratoires publics ou privés. 
Pharmacological insight into the activation of the human neuropeptide

FF2 receptor

Franck Talmont a,b, *, Remi Veneziano a,b , Gilles Dietrich c, Lionel Moul ' edous a,b ,

Catherine Mollereau a,b , Jean-Marie Zajac a,b

a CNRS, IPBS (Institut De Pharmacologie Et De Biologie Structurale) 205 Route De Narbonne, 31077

Toulouse, Cedex 4, France

b Universit ' e Paul Sabatier Toulouse III, F-31300 Toulouse, France

c INSERM IRSD (Institut De Recherche En Sant 'e Digestive) U1220, CHU Purpan Place Du Docteur Baylac, CS 60039 31024, Toulouse Cedex 3, France

Keywords: G protein coupled receptor GPCR NPFF peptide NPFF 2 receptor Neuropeptide

* Corresponding author at: CNRS, IPBS (Institut de Pharmacologie et de Biologie Structurale) 205 route de Narbonne, 31077 Toulouse, Cedex 4, France.

E-mail address: franck.talmont@ipbs.fr (F. Talmont).

Contents lists available at ScienceDirect

Peptides journal homepage: www.elsevier.com/locate/peptides

https://doi.org/10.1016/j.peptides.2020.170406

Received 10 April 2020; Received in revised form 13 August 2020; Accepted 8 September 2020

Peptides 134 (2020) 170406

\section{A B S T R A C T}

The neuropeptide FF2 (NPFF2) receptor, predominantly expressed in the central nervous system, plays an important role in the modulation of sensory input and opioid analgesia, as well as in locomotion, feeding, intestinal motility, reward, and the control of obesity. The NPFF2 receptor belongs to the RFamide peptide receptor family and to the $G$ protein coupled receptor (GPCR) super family, but contrary to many other class A GPCRs, no 3D structure has been solved. Thus, it is essential to perform mutagenesis to gain information on the fine functioning of the NPFF2 receptor. In this study, we examined the role of aspartic acid (D) from the "D/ERY/F" motif found in the second intracellular loop (ICL2) and the role of the C-terminal end of the receptor in ligand binding and signal transduction. We found that mutation D3.49A does not impair binding capacities but inhibits $G$ protein activation as well as adenylyl cyclase regulation. Truncation of the $C$ terminal part of the receptor has different effects depending on the position of truncation. When truncation was realized downstream of the putative acylation site, ligand binding and signal transduction capabilities were not lost, contrary to total deletion of the $\mathrm{C}$ terminus, which totally impairs the activity of the receptor.

1. Introduction

The neuropeptide FF2 (NPFF2) receptor belongs to the RFamide peptide receptor family and to the G protein coupled receptor (GPCR) 
super family [31]. The NPFF2 receptor and its closest homologue (50\% homology), the neuropeptide FF1 (NPFF1) receptor, are activated by the neuropeptide FF (NPFF; FLFQPQRF-NH2) [16]. This peptide and other related peptides are generated from two precursors, pro-NPFFA and pro-NPFFB [17]. The NPFF system is known as an anti-opioid effector since NPFF and NPFF-like peptides can oppose some of the acute effects of opioids [17]. Just like the NPFF peptide, the NPFF2 receptor is predominantly expressed in the central nervous system in accordance with its role in the modulation of sensory input and opioid analgesia. In addition to their implications in pain perception and opioid modulation, NPFF peptides and receptors have demonstrated roles in locomotion, feeding, intestinal motility, reward, and the control of obesity $[12,15$, 21]. Since the first $X$-ray crystal structure determination of bovine rhodopsin [19], an increasing number of 3D structures of GPCR have been solved [30]. Together with site-directed mutagenesis and domain deletion, techniques for the determination of 3D structure are powerful methods for providing insight into how a GPCR works. Nevertheless, to provide relevant structure - function information, these techniques must be combined and interact closely. Until recently, no 3D structure has been solved for the NPFF2 receptor, it is thus essential to perform mutagenesis to gain information on its fine functioning. Since this receptor belongs to the class A GPCR family [11], it shares structural domains, amino acids, and functional similarities with other class A receptors. These receptors have $\mathrm{N}$ - and $\mathrm{C}$-terminal tails in their extracellular and intracellular compartments respectively. They are constituted with seven $\alpha$-helices crossing the membrane and with a putative eighth helix located immediately after the seventh transmembrane helical domain (Fig. 1). However, there is limited information regarding the structure - function of the NPFF2 receptor [6,7] performed by site-directed mutagenesis. Here, we present the pharmacological profile of the NPFF2 receptor mutated at the aspartic acid (D) site in the 
D/ERY/F" motif in the second intracellular loop (ICL2), known to be involved in GPCR activation [14,22,26,32]. We also investigated the effect of truncation of the C-terminal end, a domain involved in receptor signaling $[4,18,20]$.

2. Materials and methods

\subsection{Materials}

NPFF-related peptides were synthesized in-house using manual solid phase synthesis with Fmoc-amino acid chemistry. Peptides used were: NPSF: SLAAPQRF-NH2, NPFF: FLFQPQRF-NH2, NPAF: NPAFLFQPQRFNH2, NPVF: VPNLPQRF-NH2, 1DMe: ([D.Tyr1, (NMe) Phe3] NPFF), SQA-NPFF: SQAFLFQPQRF-NH2. The NPFF antagonist RF9 [25] was synthesized at Universit 'e Louis Pasteur, Illkirch, France. [3H]-EYF, 72 $\mathrm{Ci} / \mathrm{mmol}(2.66 \mathrm{~T} \mathrm{~Bq} / \mathrm{mmol})$, was custom made by RC TRITEC AG (Teufen, Switzerland) by hydrogenation of the EYWS (3-4 dehydro) LAAPQRFa precursor with $99 \%$ tritium gas [27].

\subsection{Construction of human neuropeptide FF2 receptor mutants}

Mutagenesis was performed on the human NPFF2 receptor cloned in pBluescript II (SK) + . The D3.49A mutation was realized by polymerase chain reaction using the primers 5 'TGCAATTGCTGTAGCTAGGTTCCAGTGTGT3' and 5 ' TTTCCTGATTTGGCCAGTCTTCCCG3 ' to amplify a 233 bp double strand cDNA. This fragment was cloned in a TOPO TA cloning vector (Invitrogen), cut with Mfel and Bbsl enzymes and inserted at the same sites in the human NPFF2 receptor pBluescript II $(\mathrm{SK})+$. After digestion with BamHI and Xbal, the D3.49A hNPFF2 receptor sequence was inserted into the bicistronic pEFIN3 vector [13]. For construction of the deleted C-terminal receptors, a unique 5 'oligonucleotide was used, 5' GgaAATgaggaAgATCTACACCACT3', and two 3 'primers, 5 ' TCTAGATTACTTTGCTCTTTTTTGGCA3 ' ( $\triangle$ C63-hNPFF2 receptor) and 5 ' TCTAGATTAGCGGAAATTCTCGTT3 ' ( $\triangle$ C80-hNPFF2 receptor). The double strand cDNAs $(445 \mathrm{bp}$ for the $\triangle$ C63-NPFF2 receptor and $394 \mathrm{bp}$ for the $\triangle$ C80-NPFF2 receptor) were cloned into a TOPO TA cloning vector, cut with 
$\mathrm{BgI} 2$ and Xbal restriction enzymes and cloned into the hNPFF2 receptor pBluescript II (SK) + vector. After digestion with BamHI and Xbal restriction enzymes, the $\triangle$ C63-hNPFF2 receptor and the $\Delta$ C80-hNPFF2 receptor were inserted into the bicistronic pEFIN3 vector [13]. The sequences were confirmed by DNA sequencing.

\subsection{Cell expression and transfection}

Chinese hamster ovary $(\mathrm{CHO})$ cell line was stably transfected with the mutant receptor constructs using fugene 6 according to the manufacturer' s instructions (Roche Applied Science, France). Selection was achieved by adding $400 \mathrm{mg} / \mathrm{mL}$ geneticin (G418, Invitrogen, France) to the culture medium. Individual clones were isolated by limit dilution in 96-well plates. $\mathrm{CHO}$ cell lines expressing mutant and wild type receptors were grown in Ham 's F12 nutrient mixture medium supplemented with $10 \%$ fetal bovine serum, $100 \mathrm{U} / \mathrm{mL}$ penicillin, $100 \mathrm{mg} / \mathrm{mL}$ streptomycin, (Gibco-BRL, France), and 400 mg/mL G418 (Gibco-BRL, France) to maintain the selection of recombinant cells.

\subsection{Membrane preparation}

Cells were harvested in phosphate buffered saline (PBS), frozen for at least for $1 \mathrm{~h}$ at $80 \circ \mathrm{C}$, and then homogenized with a Potter Elvehjem tissue grinder in an ice-cold buffer composed of $50 \mathrm{mM}$ Tris $\mathrm{HCl}(\mathrm{pH}$ 7.4). The nuclear pellet was discarded by centrifugation at $1000 \mathrm{~g}$ for 15 $\min$ at $4 \circ \mathrm{C}$, and the membrane fraction was collected upon centrifugation of the supernatant at $100,000 \mathrm{~g}$ for $35 \mathrm{~min}$ at $4 \circ \mathrm{C}$. Membranes were aliquoted in Tris $\mathrm{HCl}(50 \mathrm{mM}, \mathrm{pH}$ 7.4) buffer and stored at 80 $\circ \mathrm{C}$. The protein concentration was determined by the Bradford method.

\subsection{Binding experiments}

Binding of $[3 \mathrm{H}]-\mathrm{EYF}$ was measured by rapid filtration. Cell membranes (1 $\mu \mathrm{g}$ hNPFF2 receptor to $10 \mu \mathrm{g} \Delta$ C63-hNPFF2 receptor) were incubated in polypropylene tubes in a final volume of $500 \mu \mathrm{L}$ containing $50 \mathrm{mM}$ Tris $\mathrm{HCl}(\mathrm{pH} 7.4), 60 \mathrm{mM} \mathrm{NaCl}, 0.1 \%$ bovine serum albumin (Sigma, France), and, lastly, increasing concentrations of the [3H]-EYF 
radioligand. Non-specific binding was determined in the presence of one $\mu$ M EYF. For competition studies, increasing concentrations of cold ligands (1DMe, NPFF, SQA-NPFF, NPSF, NPVF, NPAF, RF9) were used to displace the binding of $1-2 \mathrm{nM}[3 \mathrm{H}]-\mathrm{EYF}$. After $1 \mathrm{~h}$ of incubation at 25 - C, samples were rapidly filtered on Whatman GF/B filters presoaked in $0.3 \%$ polyethylenimine. The filters were rinsed 3 times with $4 \mathrm{~mL}$ of icecold buffer containing $0.1 \%$ bovine serum albumin, and the bound radioactivity was counted in a liquid scintillation spectrophotometric counter (Packard).

2.6. Assay for intracellular $3^{\prime}, 5^{\prime}$-cyclic adenosine monophosphate An assay for intracellular $3^{\prime}, 5^{\prime}$-cyclic adenosine monophosphate (cAMP) was performed as previously described [16]. In this procedure, 200,000 recombinant cells were incubated for one hour at $37 \circ \mathrm{C}$ under an atmosphere of $5 \% \mathrm{CO} 2$ with $0.6 \mathrm{mCi}[3 \mathrm{H}]$ adenine $(26 \mathrm{Ci} / \mathrm{mmol}, \mathrm{GE}$ Healthcare) in Ham ' s F12 medium. cAMP production was stimulated by $5 \mu$ M Forskolin (Sigma, France) for 10 min at $37 \circ \mathrm{C}$ in $200 \mu$ L HEPES ([4-(2-hydroxyethyl)-1-piperazineethanesulfonic acid])-buffered Krebs - Ringer solution in the presence of $0.1 \mathrm{mM}$ of the phosphodiesterase inhibitors IBMX (Sigma, France) and Ro-20 1724 (Fisher, France). The desired concentration of the tested ligands were added and the reaction was stopped by the addition of $20 \mu \mathrm{L}$ of $\mathrm{HCl}(2.2 \mathrm{~N})$ and rapid mixing. The $[3 \mathrm{H}]$ cAMP content of each tube was isolated by chromatography on acidic alumina columns (Sigma, France) and counted in a liquid scintillation analyzer (Packard).

\section{7. [35S] GTP $\gamma \mathrm{S}$ binding assay}

The assay buffer consisted of $20 \mathrm{mM}$ HEPES (pH 7.4), $20 \mathrm{mM}$ or 150 $\mathrm{mM} \mathrm{NaCl}, 3 \mathrm{mM} \mathrm{MgCl}$, $1 \mu \mathrm{M} \mathrm{GDP}$ (guanosine-5 ' -diphosphate) and 0.1 \% BSA (bovine serum albumin). Membranes were incubated in polypropylene tubes at $30 \circ \mathrm{C}$ for $60 \mathrm{~min}$ in $500 \mu \mathrm{L}$ of buffer containing 0.05 $\mathrm{nM}[35 \mathrm{~S}] \mathrm{GTP} \gamma \mathrm{S}$. The reaction was stopped by rapid filtration, and the radioactivity was detected and counted in a Packard liquid scintillation 
analyzer.

\subsection{Western blot analysis}

Proteins from $\mathrm{CHO}$ membranes were separated according to their size by $10 \%$ sodium dodecyl sulfate (SDS) polyacrylamide gel electrophoresis and transferred onto an immun-blot polyvinylidene fluoride (PVDF) membrane (Bio-Rad Laboratories, Hercules, CA). The receptors were probed with hNPFF2-primed mouse immune sera (1:1000) [28]. Bound immunoglobulin $\mathrm{G}$ ( $\operatorname{IgG}$ ) was revealed using horseradish peroxidase-labeled sheep anti-mouse IgG antibodies diluted at 1:10000 (Jackson Immunoresearch Lab, West Grove, PA).

\subsection{Analysis of the data}

Non-linear regression analyses of the data were performed using Prism 4.0 software (GraphPad Inc., USA).

\section{Results}

We constructed three mutants of the hNPFF2 receptor (Fig. 1) and analyzed the effects of each mutant on ligand interaction and signal transduction. The first mutant (D3.49A-hNPFF2 receptor) was created by changing the amino acid aspartic acid (D), located at the interface between transmembrane helix three (TM3) and intracellular loop (ICL2), to alanine (A). This mutant was designated using the Ballesteros and Weinstein nomenclature [1] and belongs to the highly conserved E/DRY/F motif of class A GPCRs. The two other mutants were C-terminal end deleted, with one next to the interface between transmembrane helix seven (TM7) and the $C$ terminus ( $\triangle$ C80-hNPFF2 receptor) and the second downstream to a putative palmitoylation site ( $\triangle$ C63-hNPFF2 receptor).

\subsection{Binding of the agonist [3H]-EYF}

Saturation binding curves were established with a membrane fraction using the tritiated agonist compound [3H]-EYF [27] (Fig. 2). The results obtained for the mutants were compared with the wild type receptor (Table 1). A slight decrease in affinity was observed for the 
$\triangle$ C63-hNPFF2 and D3.49A-hNPFF2 receptors mutants compared to the wild type, but KD values were all in the $\mathrm{nM}$ range. The $\triangle \mathrm{C} 80$-hNPFF2 receptor mutant was unable to bind the specific agonist ligand EYF. The clone that express $\Delta$ C80-hNPFF2 receptor was resistant to G418 and the expression of the mutant was confirmed by Western blot (data not show).

\subsection{Competition binding assays}

Competition experiments (Table 2, Fig.3) were then performed to compare the pharmacological binding profile of wild type and mutant hNPFF2 receptors. All peptides used in this study belong to the RF-amide peptide family $[5,17]$. They are all agonists to NPFF receptors except RF9 that is an antagonist [25]. Two peptides precursors have been identified in mammals. NPFF, 1DMe which is a stable NPFF analogue, SQA-NPFF, NPSF and NPAF are pro-NPFFA-derived peptides whereas NPVP is a pro-NPFFB-derived peptide. The utilization of these peptides allow to make pharmacological profiles on NPFF receptors and mutants due to their different selectivity on NPFF type 1 and 2 receptors $[5,6,16]$. For the D3.49A-hNPFF2 receptor, the rank order of the potency of the inhibition of specific [3H]-EYF binding by seven ligands was SQA-NPFF $\geq 1$ DMe $\geq$ NPAF $>$ NPFF $>$ NPSF $>$ RF9 $\geq$ NPVF. For the $\triangle$ C63-hNPFF2 receptor, the order was SQA-NPFF $>$ NPAF $\geq N P F F \geq 1$ DMe $>$ NPVF $>$ NPSF > RF9. The Ki values measured for the D3.49A-hNPFF2 receptor were very similar to those of the wild type receptor, except for RF9, which was four-fold more potent for the mutant. For the mutant $\triangle$ C63-hNPFF2 receptor, the tested ligand was globally as potent as the wild type receptor.

3.3. Binding of [35S]-GTP $\gamma S$ to the G proteins in wild type and mutant Chinese hamster ovary (CHO)-NPFF2 receptor membranes Stimulation of [35S] GTP $\gamma$ S binding by 1DMe was assessed, and EC50 and Emax parameters were determined from the concentration - response curves (Table 3, Fig.4). Experiments were performed under low (20 mM) 
and high sodium $(150 \mathrm{mM})$ conditions. High $\mathrm{Na}+$ concentration is suspected to unmask the constitutive activity of receptors [9]. No stimulation was observed for the $\Delta$ C80-hNPFF2 receptor, in accordance with the absence of binding, and, unexpectedly, for the D3.49A-hNPFF2 receptor mutant. A comparison of the EC50 values of hNPFF2 and $\triangle$ C63-hNPFF2 receptors revealed a decrease in potency for the mutant at low $\mathrm{Na}+(\mathrm{EC50}, 17$-fold higher) and at high $\mathrm{Na}+$ concentrations (EC50, 3.5-fold higher). The rightward shift of the curve induced by high $\mathrm{NaCl}$ concentrations was less pronounced in the $\triangle$ C63-hNPFF2 receptor (8-fold) compared to that of the wild type receptor (40-fold). The Emax between the low and high $\mathrm{NaCl}$ conditions increased by a factor two for the $\triangle$ C63-hNPFF2 receptor, whereas there was a four-fold increase for the wild type receptor.

\subsection{Ligand-induced cAMP accumulation}

As for the stimulation of [35S]-GTP $\gamma \mathrm{S}$ binding, the $\Delta$ C63-hNPFF2 receptor was the only mutant able to mediate the inhibition of the forskolin-induced accumulation of CAMP by the agonists (Fig. 5). The rank orders of ligand potencies in wild type hNPFF2 and mutant $\triangle$ C63hNPFF2 receptors were very similar (NPAF $\geq$ SQA-NPFF $>1$ DMe $>$ NPVF $>$ NPSF $>>$ RF9 for wild type and SQA-NPFF $\geq$ NPAF $>1$ DMe $>$ NPSF $>$ NPVF > RF9 for $\triangle$ C63-hNPFF2 receptor). However, the potencies decreased 10 -fold in compared to the wild type receptor (Table 4). Concerning these receptors, the inhibition constants (Ki) were related to the functional potencies (EC50) for nearly all peptides tested, indicating that the agonist activity reflected the binding affinity.

\section{Discussion}

In the present study, mutants of the hNPFF2 receptor (Fig. 1) were generated and transfected in $\mathrm{CHO}$ cells. The mutants were analyzed for their ability to interact with ligands specific for the human NPFF2 receptor and for their capacity to activate signal transduction cascades. For the first mutant D3.49A-hNPFF2 receptor, the aspartic acid at the 
ICL2 glutamic acid/aspartic acid-arginine-tyrosine/phenylalanine (D/ $E R Y / F)$ motif was mutated to alanine and the two other mutants were $C$ terminal truncated forms of the hNPFF2 receptor. The ICL2 "D/ERY/F" motif is a highly conserved motif among GPCRs [26]. It is located at the cytoplasmic interface between TM3 and ICL2. This motif is usually known as a DRY motif (position 3.49 - 3.51 in the Ballesteros nomenclature). The mutant D3.49A-hNPFF2 receptor displays a 3-fold decrease in $[3 \mathrm{H}]-\mathrm{EYF}$ affinity compared to the wild type. Competition studies against the tritiated ligand [3H]-EYF have shown no change in affinity for various specific ligands, except for the antagonist RF9, whose affinity increased by a factor of four. In contrast, the signal transduction pathway was deeply impaired since neither G-protein coupling nor adenylate cyclase activation were observed for this mutant. An ionic lock was detected in the rhodopsin crystal structure where arginine (3.50) is engaged in a double salt bridge with glutamic acid (3.49) and another glutamic acid (6.30) positioned on helix six [19]. It was proposed that breaking these interactions might have important consequences in the activation of rhodopsin. The mutation of aspartic/glutamic acid (3.49) in class A GPCRs has various effects on ligand binding and signal transduction. The aspartic acid to asparagine, lysine, or arginine mutations (D3.49 N, D3.49 K, D3.49R) in the adenosine A3 receptor and expressed in COS-7 cells have no impact on agonist binding affinity, cAMP production, and phospholipase $\mathrm{C}$ activation [3]. On the contrary, the human D3.49 CXCR1 mutants (D3.49 N and D.3.49 V) expressed in HEK 293 cells were not able to bind specific ligands and did not retain $\mathrm{G}$ protein coupling and agonist-induced responses [10]. In rhodopsin, the ionically charged pair E3.49/R3.50 found in the DRY motif was mutated to R3.49/E3.50, and this mutant normally binds 11-cis-retinal to yield pigments with native rhodopsin absorption spectra, but it failed to stimulate the G protein [8]. In the human $\beta 2$ adrenergic receptor, it was suggested that D3.49 (Asp-130) is 
an important part of a molecular switch that controls the transition of the receptor between its active and inactive state, and, thus, it may govern the spatial disposition of TMs 3 and 6 [22]. In the hNPFF2 receptor, intramolecular interactions between the DRF amino acids cluster and an amino acid located in the TM6 helix remain to be verified. Thus, replacing the charged aspartic acid residue located in the highly conserved D/ERY/F motif with the non-polar amino acid alanine has a slight effect on the ligand binding affinities. In fact, the interaction between hNPFF2 receptor and specific ligands is located in a binding pocket narrowed down to the upper part of transmembrane helices 5, 6, and 7 and the extracellular loop 2 [7]. The Beck-Sickinger group performed an important work [7] to investigate this binding pocket of NPFF receptors after mutagenesis of key residues.

However, this D3.59A amino acid modification has a huge effect on the ability of the receptor to transduce a signal after ligand interaction, suggesting the involvement of this amino acid in a conformational structure with $G$ proteins. It seems possible that the loss of function of the mutant D3.49A-hNPFF2 receptor and its higher affinity for the antagonist RF9 reflects an inactive and uncoupled intermediary conformation of the receptor. The C-terminal end of class A GPCRs interacts with $G$ proteins and interferes with signal transduction when modified. The conformational structure of the C-terminus of a GPCR, its ability to interact with $\mathrm{G}$ proteins, and its role in signal transduction depends on its composition in amino acids (e.g., phosphorylation sites [2]) (Fig. 1), and the occurrence of an amphipathic eighth $\alpha$-helix [23]. In the mutant $\triangle$ C63-hNPFF2, deletion of 63 amino acids from the C-terminal end of the hNPFF2 receptor, which was realized downstream of the helix8, had a slight effect on the binding of [3H]-EYF (Fig. 2, Table 1) and on the ability of the ligand to compete with [3H]-EYF (Fig. 3, Table 2). The decrease in stimulation of [35S]-GTP $\gamma \mathrm{S}$ binding with 1DMe at high and low $\mathrm{NaCl}$ concentrations (Fig. 4, Table 3) was in 
accordance with the decrease in 1DMe binding affinity. Nevertheless, we can observe a more significant decrease in potency and relative efficacy of [35S]-GTP $\gamma \mathrm{S}$ stimulation by 1DMe (Table 3) for the $\Delta$ C63 mutant relative to wild type at low salt than in high salt. This effect has already been observed for partial agonist compared to full agonist [24,33]. The effect of the deletion of the C-terminal part of the receptor seems to be comparable to that observed for partial agonists in other systems. The cAMP signal transduction pathway that follows $\mathrm{G}$ protein activation was more affected (Fig. 5, Table 4), and EC50 values increase by a factor $10-30$, depending on the ligand considered. In the hNPFF2 receptor, eight residues can be phosphorylated at the C-terminal part, either in the basal state or after agonist treatment [2], and as for the results obtained for the deletion in the $\triangle$ C63-hNPFF2 receptor mutant, the removal of individual conserved phosphorylation sites does not strongly affect NPFF2 receptor signaling [2]. Truncation of the C-terminal parts of human mu opioid receptor ( $\Delta$ C45hMOR) [4] and mouse delta opioid receptor ( $\triangle$ C31mMOR) [34] expressed in $\mathrm{CHO}$ cells, downstream of the putative palmitoylation site (thus defining a 4th $I C L$ ), has no impact on the binding affinity of specific ligands and on the inhibition of forskolin-stimulated cAMP accumulation after exposure to the agonist. Our results obtained for the $\Delta$ C63-hNPFF2 mutant receptor prompted us to analyze a mutant with a total C-terminal amino acid truncation, namely the $\triangle$ C80-hNPFF2 receptor mutant. Contrary to the $\triangle$ C63-hNPFF2 receptor mutant, no binding was observed in the [3H-EYF] saturation test. No positive results were obtained in the stimulation of [35S] GTP $\gamma \mathrm{S}$ binding and CAMP accumulation tests, despite the detection of the protein by Western blot (data not shown). The absence of crystallographic data for the NPFF2 receptor does not allow for clear positioning of the structural domains that compose the protein e.g., TM7 or helix eight. However, the position of the $\Delta \mathrm{C} 80$ truncation could be at the level of the putative helix eight, which would 
indicate an essential role of this domain in receptor binding and signaling. The specific amino acid composition of the C-terminus is not the only actor that trigger receptor activity. Post-translational modification such as palmitoylation, O-glycosylation or phosphorylation are also important. Moreover, the activity of GPCR depend on the type of G-proteins or $\beta$-arrestins and channels, which may vary in cells and tissues.

In conclusion, the replacement of aspartic acid 3.49 with alanine from the highly conserved ICL2 "D/ERY/F" motif does not impair the binding capacities of receptor-specific ligands. On the other hand, this amino acid is essential with regard to signal transduction since the activation of $\mathrm{G}$ proteins by the ligand as well as the capacity to inhibit the activity of adenylyl cyclase were totally damaged. Truncation of the C-terminal part of the receptor has different effects depending on the position of the truncation. When the truncation was realized downstream of the putative acylation site ( $\triangle$ C63-hNPFF2 receptor), ligand binding and signal transduction capabilities were not lost, although they were less efficient than for the entire receptor. On the contrary, total deletion of the C-terminus ( $\triangle \mathrm{C} 80$-hNPFF2 receptor) totally impairs the activity of the receptor. This suggests that this domain, comprising the putative eighth $\alpha$-helix and acylation site, is essential for the correct folding of the receptor.

\section{Acknowledgement}

The authors acknowledge financial support from the Centre National de la Recherche Scientifique (CNRS).

\section{References}

[1] J.A. Ballesteros, H. Weinstein, Integrated methods for the construction of threedimensional models and computational probing of structure-function relations in $\mathrm{G}$ protein-coupled receptors, Methods in Neurosci. 25 (1995) $366-428$.

[2] L. Bray, C. Froment, P. Pardo, C. Candotto, O. Burlet-Schiltz, J.M. Zajac, et al., 
Identification and functional characterization of the phosphorylation sites of the neuropeptide FF2 receptor, J. Biol. Chem. 289 (2014) 33754 - 33766.

[3] A. Chen, Z.G. Gao, D. Barak, B.T. Liang, K.A. Jacobson, Constitutive activation of A (3) adenosine receptors by site-directed mutagenesis, Biochem. Biophys. Res. Commun. 284 (2001) 596-601.

[4] H.B. Deng, Y. Yu, Y. Pak, B.F. O ' Dowd, S.R. George, C.K. Surratt, et al., Role for the C-terminus in agonist-induced mu opioid receptor phosphorylation and desensitization, Biochemistry 39 (2000) $5492-5499$.

[5] M. Findeisen, D. Rathmann, A.G. Beck-Sickinger, RFamide Peptides: Structure, Function, Mechanisms and Pharmaceutical Potential, Pharmaceuticals 4 (2011) $1248-1280$.

[6] M. Findeisen, D. Rathmann, A.G. Beck-Sickinger, Structure-activity studies of RFamide peptides reveal subtype-selective activation of neuropeptide FF1 and FF2 receptors, Chem. Med. Chem. 6 (2011) $1081-1093$.

[7] M. Findeisen, C. Wurker, D. Rathmann, R. Meier, J. Meiler, R. Olsson, et al., Selective mode of action of guanidine-containing non-peptides at human NPFF receptors, J. Med. Chem. 55 (2012) 6124-6136.

[8] R.R. Franke, B. Konig, T.P. Sakmar, H.G. Khorana, K.P. Hofmann, Rhodopsin mutants that bind but fail to activate transducin, Science 250 (1990) $123-125$. [9] C. Gouarderes, H. Mazarguil, C. Mollereau, N. Chartrel, J. Leprince, H. Vaudry, et al., Functional differences between NPFF1 and NPFF2 receptor coupling: high intrinsic activities of RFamide-related peptides on stimulation of [35S]GTPgammaS binding, Neuropharmacology 52 (2007) $376-386$.

[10] X. Han, Y. Feng, X. Chen, C. Gerard, W.A. Boisvert, Characterization of G protein coupling mediated by the conserved D134(3.49) of DRY motif, M241(6.34), and F251(6.44) residues on human CXCR1, FEBS Open Bio 5 (2015) 182 - 190.

[11] V. Isberg, C. de Graaf, A. Bortolato, V. Cherezov, V. Katritch, F.H. Marshall, et al., Generic GPCR residue numbers - aligning topology maps while minding the gaps, Trends Pharmacol. Sci. 36 (2015) $22-31$.

[12] J.H. Jhamandas, V. Goncharuk, Role of neuropeptide FF in central cardiovascular and neuroendocrine regulation, Front. Endocrinol. (Lausanne) 4 (2013) 8. 
[13] M. Kotani, C. Mollereau, M. Detheux, E. Le Poul, S. Brezillon, J. Vakili, et al., Functional characterization of a human receptor for neuropeptide FF and related peptides, Br. J. Pharmacol. 133 (2001) $138-144$.

[14] J. Li, P. Huang, C. Chen, J.K. de Riel, H. Weinstein, L.Y. Liu-Chen, Constitutive activation of the mu opioid receptor by mutation of D3.49(164), but not D3.32 (147): D3.49(164) is critical for stabilization of the inactive form of the receptor and for its expression, Biochemistry 40 (2001) $12039-12050$.

[15] Y.T. Lin, J.C. Chen, Neuropeptide FF modulates neuroendocrine and energy homeostasis through hypothalamic signaling, Chin. J. Physiol. 62 (2019) $47-52$.

[16] C. Mollereau, H. Mazarguil, D. Marcus, I. Quelven, M. Kotani, V. Lannoy, et al., Pharmacological characterization of human NPFF(1) and NPFF(2) receptors expressed in $\mathrm{CHO}$ cells by using NPY Y(1) receptor antagonists, Eur. J. Pharmacol. $451(2002) 245-256$.

[17] L. Mouledous, C. Mollereau, J.M. Zajac, Opioid-modulating properties of the neuropeptide FF system, Biofactors 36 (2010) $423-429$.

[18] T. Okura, E.V. Varga, Y. Hosohata, E. Navratilova, S.M. Cowell, K. Rice, et al., Agonist-specific down-regulation of the human delta-opioid receptor, Eur. J. Pharmacol. 459 (2003) 9-16.

[19] K. Palczewski, T. Kumasaka, T. Hori, C.A. Behnke, H. Motoshima, B.A. Fox, et al., Crystal structure of rhodopsin: a G protein-coupled receptor, Science 289 (2000) $739-745$.

[20] H. Pankevych, V. Korkhov, M. Freissmuth, C. Nanoff, Truncation of the A1 adenosine receptor reveals distinct roles of the membrane-proximal carboxyl terminus in receptor folding and G protein coupling, J. Biol. Chem. 278 (2003) $30283-30293$

[21] P. Panula, A.A. Aarnisalo, K. Wasowicz, F.F. Neuropeptide, A mammalian neuropeptide with multiple functions, Prog. Neurobiol. 48 (1996) $461-487$. [22] S.G. Rasmussen, A.D. Jensen, G. Liapakis, P. Ghanouni, J.A. Javitch, U. Gether, Mutation of a highly conserved aspartic acid in the beta2 adrenergic receptor: constitutive activation, structural instability, and conformational rearrangement of transmembrane segment 6, Mol. Pharmacol. 56 (1999) 175 - 184. 
[23] T. Sato, T. Kawasaki, S. Mine, H. Matsumura, Functional role of the C-Terminal amphipathic Helix 8 of olfactory receptors and other g protein-coupled receptors, Int. J. Mol. Sci. 17 (2016).

[24] D.E. Selley, C.C. Cao, Q. Liu, S.R. Childers, Effects of sodium on agonist efficacy for G-protein activation in mu-opioid receptor-transfected $\mathrm{CHO}$ cells and rat thalamus, Br. J. Pharmacol. 130 (2000) $987-996$.

[25] F. Simonin, M. Schmitt, J.P. Laulin, E. Laboureyras, J.H. Jhamandas, D. MacTavish, et al., RF9, a potent and selective neuropeptide FF receptor antagonist, prevents opioid-induced tolerance associated with hyperalgesia, Proc. Natl. Acad. Sci. U.S.A. 103 (2006) $466-471$.

[26] C.K. Surratt, W.R. Adams, G protein-coupled receptor structural motifs: relevance to the opioid receptors, Curr. Top. Med. Chem. 5 (2005) $315-324$.

[27] F. Talmont, L.P. Garcia, H. Mazarguil, J.M. Zajac, C. Mollereau, Characterization of two novel tritiated radioligands for labelling Neuropeptide FF (NPFF(1) and NPFF (2)) receptors, Neurochem. Int. 55 (2009) $815-819$.

[28] F. Talmont, L. Mouledous, J. Boue, C. Mollereau, G. Dietrich, Denatured G-protein coupled receptors as immunogens to generate highly specific antibodies, PLoS One 7 (2012) e46348.

[29] F. Talmont, L. Mouledous, L. Piedra-Garcia, M. Schmitt, F. Bihel, J.J. Bourguignon, et al., Pharmacological characterization of the mouse NPFF2 receptor, Peptides 31 (2010) $215-220$.

[30] D.M. Thal, Z. Vuckovic, C.J. Draper-Joyce, Y.L. Liang, A. Glukhova,

A. Christopoulos, et al., Recent advances in the determination of $\mathrm{G}$ protein-coupled receptor structures, Curr. Opin. Struct. Biol. 51 (2018) $28-34$.

[31] M. Vass, A.J. Kooistra, D. Yang, R.C. Stevens, M.W. Wang, C. de Graaf, Chemical diversity in the g protein-coupled receptor superfamily, Trends Pharmacol. Sci. 39 (2018) $494-512$.

[32] W.I. Weis, B.K. Kobilka, The molecular basis of g protein-coupled receptor activation, Annu. Rev. Biochem. 87 (2018) 897 - 919.

[33] A.J. Williams, A.D. Michel, W. Feniuk, P.P. Humphrey, Somatostatin5 receptormediated [35S]guanosine-5 ' -O-(3-thio)triphosphate binding: agonist potencies and 
the influence of sodium chloride on intrinsic activity, Mol. Pharmacol. 51 (1997)

$1060-1069$.

[34] X. Zhu, C. Wang, Z. Cheng, Y. Wu, D. Zhou, G. Pei, The carboxyl terminus of mouse delta-opioid receptor is not required for agonist-dependent activation, Biochem. Biophys. Res. Commun. 232 (1997) $513-516$.

Table 1

Binding affinity constants (K D ) and receptor expression levels (B max ).

Binding affinity constants (K D) and receptor expression levels (B max) determined with [ $3 \mathrm{H}$ ]-EYF. * results from [20]. Data are means \pm S.E.M. of three to five experiments performed in duplicate. NA: not applicable.

\begin{tabular}{|l|c|c|}
\hline & \multicolumn{1}{|c|}{$\mathrm{K}_{\mathrm{D}}(\mathrm{nM})$} & Bmax $(\mathrm{pmol} / \mathrm{mg})$ \\
\hline WT $^{\text {hNPFF }}{ }_{2}{ }^{*}$ & $0.54 \pm 0.06$ & $16 \pm 1$ \\
\hline$\Delta{\mathrm{C} 80-\mathrm{hNPFF}_{2}}$ & NA & NA \\
\hline$\Delta$ C63-hNPFF $_{2}$ & $2.41 \pm 0.25$ & $1.1 \pm 0.09$ \\
\hline D3.49A-hNPFF $_{2}$ & $1.59 \pm 0.17$ & $0.44 \pm 0.07$ \\
\hline
\end{tabular}

Table 2

Ki values determined by displacement.

Ki values determined by displacement of [ $3 \mathrm{H}$ ]-EYF $(1-2 \mathrm{nM})$ by a series of NPFF receptor ligands. Shown data are mean $\mathrm{Ki} \pm$ standard error of the mean from three or more independent experiments. ${ }^{*}$ results from [20]. ND: not determined.

\begin{tabular}{|l|l|l|l|}
\hline & \multicolumn{1}{|c|}{$\begin{array}{c}\text { WT * } \\
\text { Ki nM }\end{array}$} & \multicolumn{1}{|c|}{$\begin{array}{c}\text { DC63 } \\
\text { Ki nM }\end{array}$} & $\begin{array}{c}\text { D3.49A } \\
\text { Ki nM }\end{array}$ \\
\hline 1DMe & $0.38 \pm 0.04$ & $1.18 \pm 0.36$ & $0.17 \pm 0.053$ \\
\hline NPFF & $0.63 \pm 0.05$ & $0.83 \pm 0.34$ & $0.73 \pm 0.014$ \\
\hline NPSF & $19 \pm 5$ & $57.9 \pm 17.3$ & $13.8 \pm 1.3$ \\
\hline
\end{tabular}




\begin{tabular}{|l|l|l|l|}
\hline SQA-NPFF & $0.14 \pm 0.03$ & $0.3 \pm 0.042$ & $0.14 \pm 0.036$ \\
\hline NPVF & $32 \pm 12$ & $54.4 \pm 12$ & $30.2 \pm 18.9$ \\
\hline NPAF & NA & $0.79 \pm 0.043$ & $0.34 \pm 0.26$ \\
\hline RF9 & $120 \pm 20$ & $81 \pm 41.5$ & $29.7 \pm 15$ \\
\hline
\end{tabular}

Table 3

Stimulation of [ 35 S]-GTP $\gamma$ S binding.

Stimulation of [ 35 S]-GTP $\gamma \mathrm{S}$ binding by 1DMe performed on CHO-hNPFF 2 wild type and mutant receptor membranes. Data are means \pm S.E.M. of three to five experiments performed in duplicate.

\begin{tabular}{|l|c|c|c|c|}
\hline & \multicolumn{2}{|c|}{$20 \mathrm{mM} \mathrm{NaCl}$} & \multicolumn{1}{c|}{$150 \mathrm{mM} \mathrm{NaCl}$} \\
\hline & EC $50(\mathrm{nM})$ & Emax \% & EC $50(\mathrm{nM})$ & Emax \% \\
\hline hNPFF 2 receptor & $0.3 \pm 0.2$ & $116 \pm 4$ & $12 \pm 3$ & $458 \pm 46$ \\
\hline$\Delta$ C63-hNPFF 2 receptor & $5 \pm 2$ & $122 \pm 2$ & $41 \pm 4$ & $233 \pm 5$ \\
\hline
\end{tabular}

Table 4

Inhibition of forkolin-induced cAMP accumulation.

Inhibition of forkolin-induced cAMP accumulation. Shown data are mean EC 50

\pm standard error of the mean from three or more independent experiments.

\begin{tabular}{|l|l|l|}
\hline & $\begin{array}{c}{ }^{*} \mathrm{WT} \mathrm{hNPFF}_{2} \\
\mathrm{EC}_{50}(\mathrm{nM})\end{array}$ & $\begin{array}{c}\Delta \mathrm{C} 63-\mathrm{hNPFF}_{2} \\
\mathrm{EC}_{50}(\mathrm{nM})\end{array}$ \\
\hline 1DMe & $2.7 \pm 0.5$ & $36.9 \pm 7.1$ \\
\hline NPSF & $222 \pm 26$ & $2276 \pm 792$ \\
\hline SQA-NPFF & $0.56 \pm 0.05$ & $6.19 \pm 0.84$ \\
\hline NPVF & $133 \pm 11$ & $4111 \pm 842$ \\
\hline NPAF & $0.53 \pm 0.03$ & $7.31 \pm 1.75$ \\
\hline RF9 & $>1000$ & $>1000$ \\
\hline
\end{tabular}


Fig. 1. Serpentine model representative of the human neuropeptide FF2 receptor. (From the GPCRDB site [11]. The arrows indicate mutants. ECL, extracellular loop; ICL, intracellular loop; N-term, Nterminal end; C-term, C-terminal end.

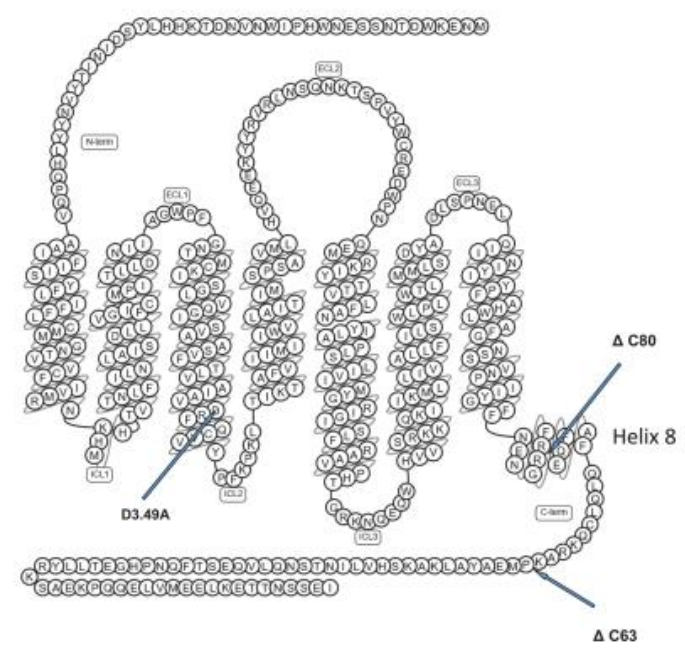

Fig. 2. Saturation binding curves of [ $3 \mathrm{H}$ ]-EYF interaction with the wild type neuropeptide FF2 receptor and mutants D3.49A-hNPFF 2 and $\triangle$ C63-hNPFF 2 receptors. binding and $\triangle$ represents nonspecific binding. The curves are representative of at least three experiments performed in duplicate. Inset: K D

and $B$ max values.
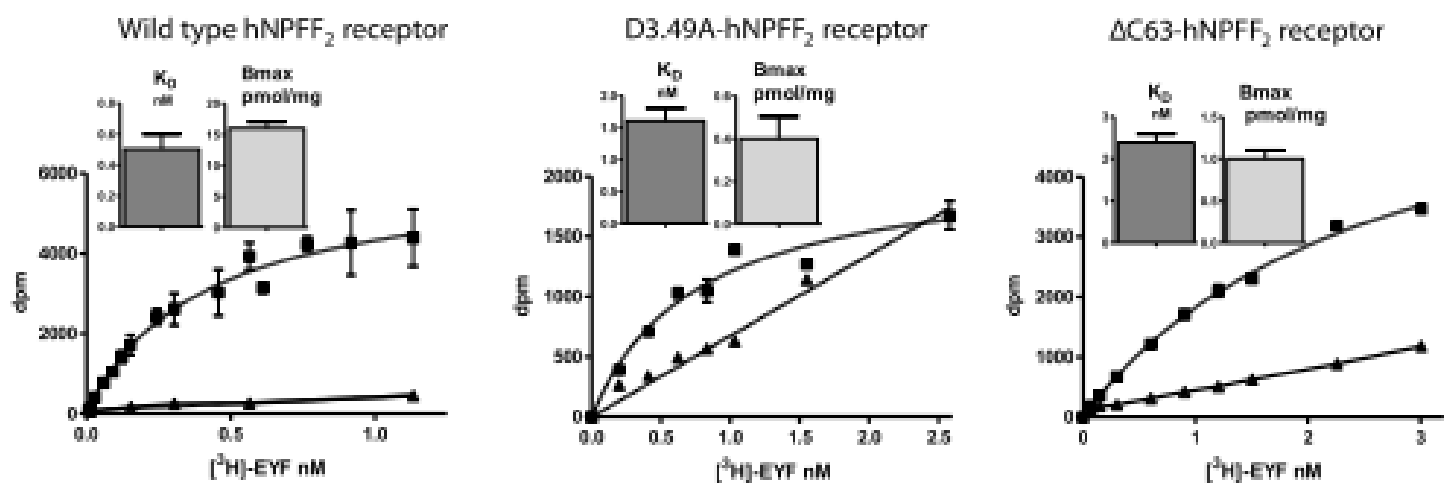

Fig. 3. Competition studies of [ $3 \mathrm{H}$ ]-EYF $(1-2 \mathrm{nM})$ with increasing concentrations of NPFF receptor ligands (1DMe, NPFF, SQA-NPFF, NPSF, NPVF, NPAF, RF9) on D3.49A-hNPFF 2 and $\triangle$ C63-hNPFF 2 receptors. The curves are representative of at least three experiments performed in duplicate. Ki $(\mathrm{nM})$ results are presented as bar graphs. 

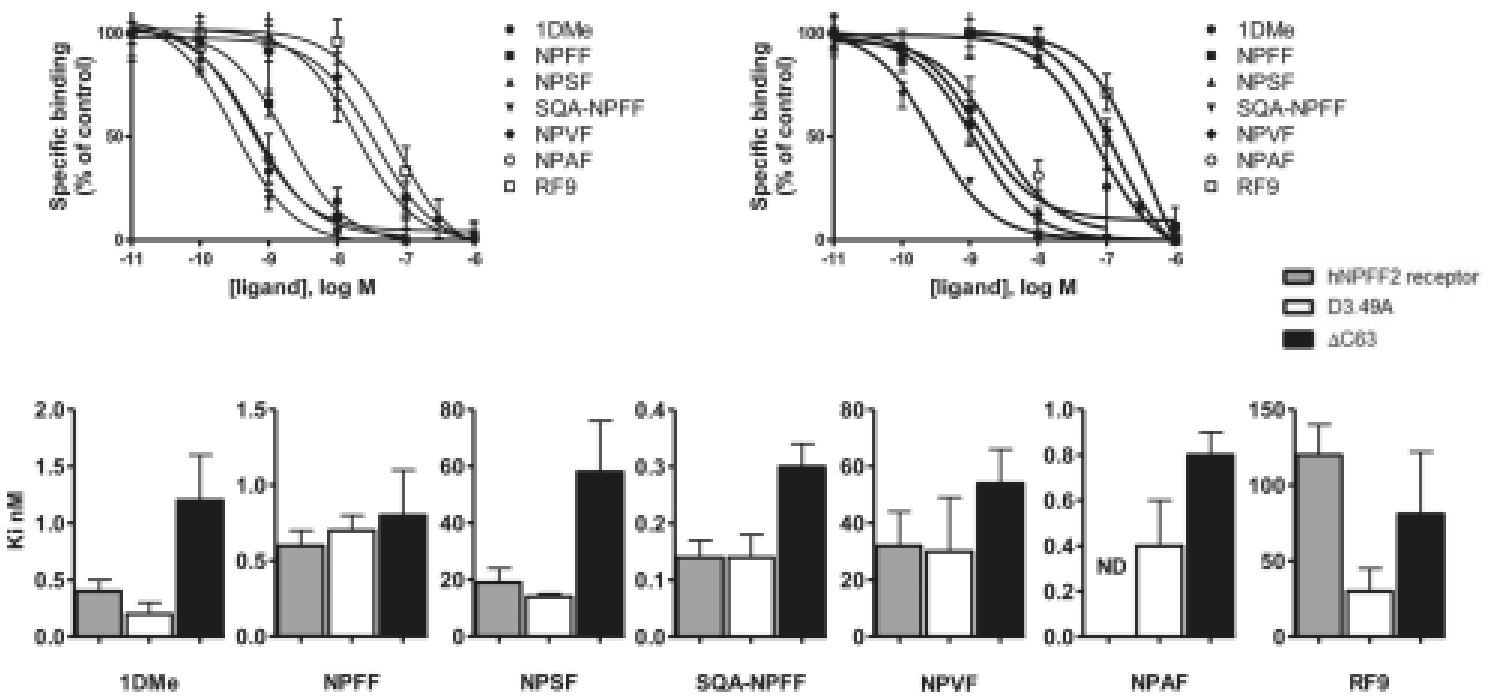

Fig. 4. [ 35 S]-GTP $\gamma \mathrm{S}$ binding induced by $1 \mathrm{DMe}$ on the wild type and mutant $\Delta$ C63-hNPFF 2 receptor membranes was realized with $1 \mu \mathrm{M}$ guanosine- $5^{\prime}$-diphosphate (GDP), various concentrations of 1DMe and $0.1 \mathrm{nM}$ [ $35 \mathrm{~S}$ ]-GTP $\gamma \mathrm{S}$. With $10 \mathrm{mM} \mathrm{NaCl}$ or $150 \mathrm{mM} \mathrm{NaCl}$. The curves are representative of at least three experiments performed in duplicate. Inset: EC 50 (nM) and Emax (\%) values.
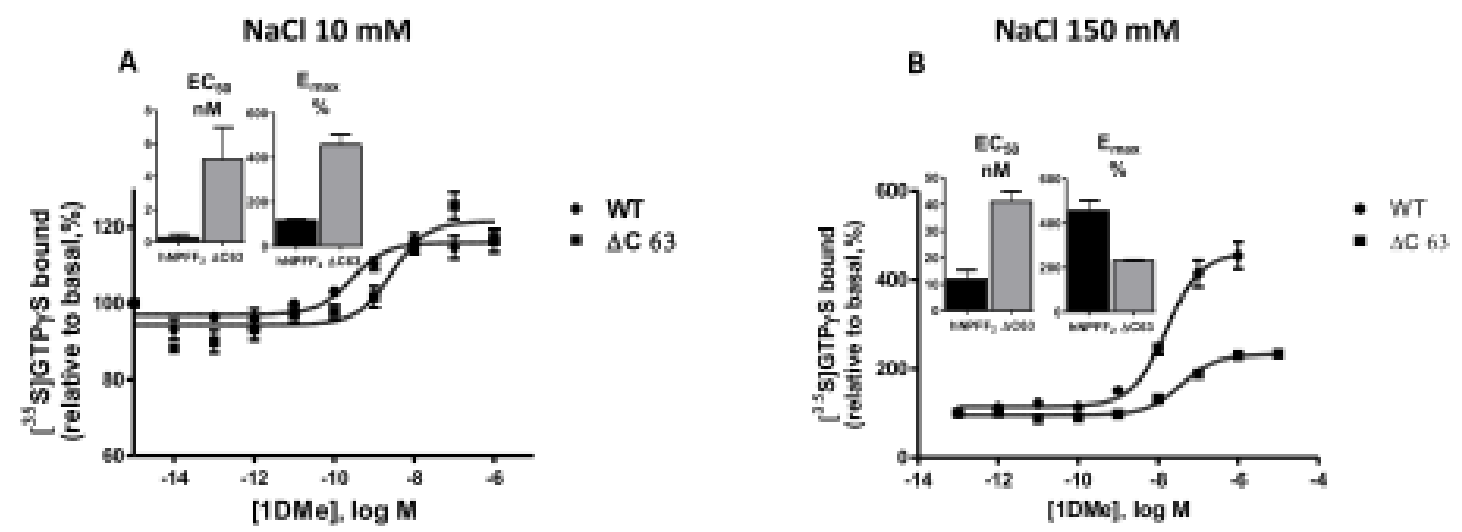

Fig. 5. Inhibition by various ligands of the forskolin-induced accumulation of $3^{\prime}, 5^{\prime}$-cyclic adenosine monophosphate (CAMP) in intact recombinant Chinese hamster ovary (CHO) cells that express the mutant $\triangle$ C63-hNPFF2 receptor. The curves are representative of at least three experiments performed in duplicate. EC 50 (nM) results are presented as bar graphs. WT h-NPFF 2 values are from $[16,29]$. 

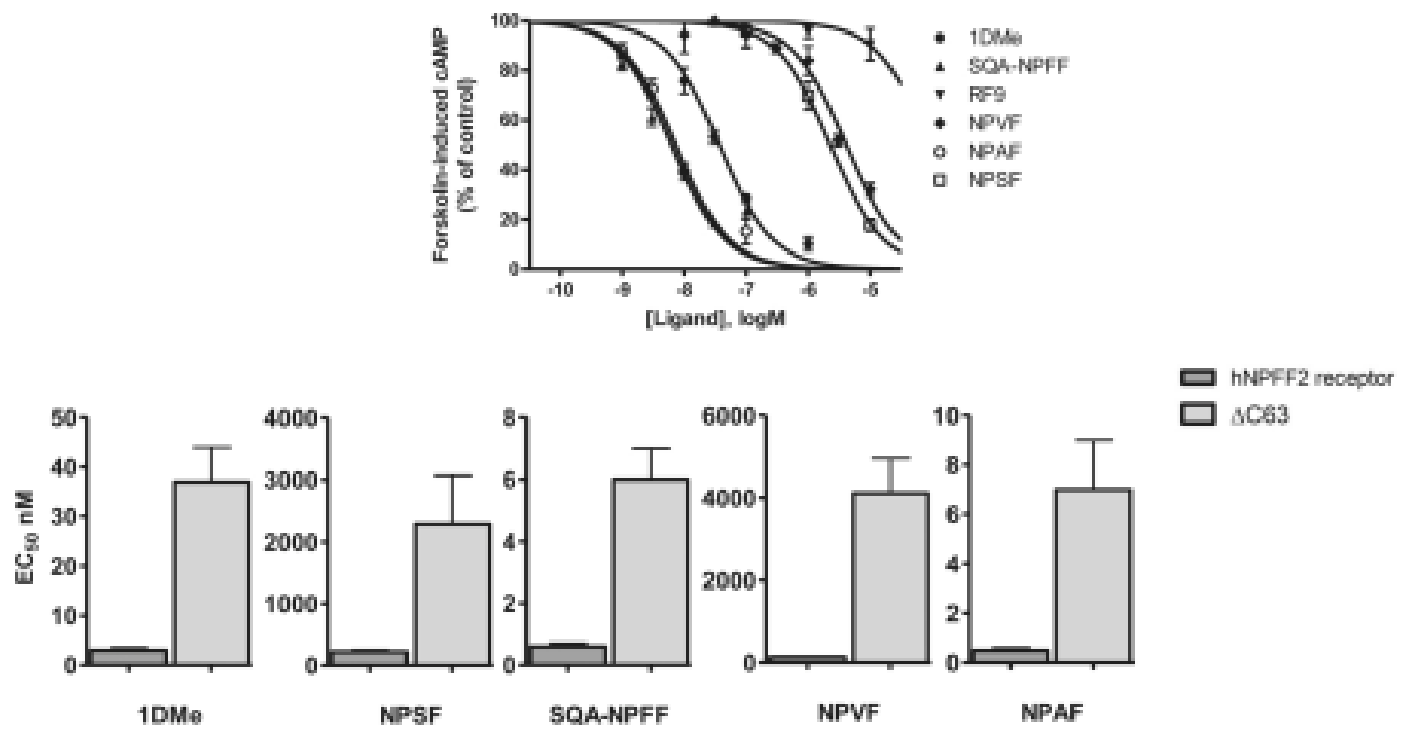